\title{
Scientific Artical of the Lecturers from the Faculty for Sport and Physical Education in Niksic Published in the Journal Sport Mont between 2016 and 2018: A Content Analysis
}

\author{
Boris Banjevic ${ }^{1}$ \\ 'Army of Montenegro, Airforce military of Montenegro, Podgorica, Montenegro
}

\begin{abstract}
Sport Mont is a scientific journal which has been existing since 2003 and it has published a great number of works of renowned scientists in the field of sport sciences and medicine. The journal has been indexed in more international database, it is released three times a year, and the published works are mostly presented on the scientific conference of the Montenegrin Sport Academy. Sport Mont, in addition to the original scientific works, publishes reviews, editorials, short reports, as well as the calls and awards for works in the field of sport sciences and medicine. This essay deals with the contents analysis of the scientific research works where the authors and co-authors are the lecturers of the Faculty for Sport and Physical Education in Nikšić, published in the journal Sport Mont between 2016 and 2018. They have been sorted according to the scientific fields they belong to, and through discussion, a short overview of the obtained results has been given. This way makes possible an easier search of the mentioned articles for the authors who express their interest for them.
\end{abstract}

Key words: Sport Science, Sport Mont, Medicine

\section{Uvod}

Crnogorska sportska akademija je osnovana 2003. godine, kada je pokrenut i naučni časopis Sport Mont. Ovaj naučni časopis ima dugogodišnju tradiciju, koja baštini visoke standarde i norme stručnog, naučnog, moralnog i etičkog digniteta. Prepoznatljiv u okruženju, regionalno i mnogo šire, Sport Mont predstavlja značajnu naučnu bazu, u kojoj se mogu naći radovi eminentnih stručnjaka iz oblasti sportskih nauka, medicine i fizičkog vaspitanja. Zapravo, on pokriva veliki broj naučnih disciplina čiji su izvori saznanja od posebnog značaja za razumijevanje brojnih kinezioloških fenomena. To se prije svega odnosi na biomehaniku, fiziologiju, kineziterapiju, fizikalnu terapiju, traumatologiju sportskih povreda, trenažnu tehnologiju, antropologiju sporta, pedagogiju-sociologiju i psihologiju sporta, sportski menadžment i sve ostale aspekte vježbanja, zdravlja i sporta. Časopis je indeksiran u 23 međunarodne naučne baze podataka, od kojih je Scopus najprestižnija. Izlazi tri puta godišnje i radovi koji su objavljeni u njemu su većinom predstavljeni na naučnoj konferenciji Crnogorske sportske akademije, koja se tradicionalno održava svake godine.

Pored originalnih naučnih radova, Sport Mont objavljuje pregledne radove, uvodnike, kratke izvještaje, nagrade radova u oblasti sportskih nauka i medicine i funkcioniše kao otvoreni forum za diskusiju o značajnim aktuelnim pitanjima. Ovaj časopis obezbjeđuje transparentnost i dostupnost naučnim radnicima širom svjetskih meridijana. Stoga, on pruža online otvoren pristup, brzo objavljivanje, mišljenje stručnjaka i istraživača, post publikacijske alate za pokazivanje kvaliteta i učinka, zajednicu zasnovanu na zajedničkom jeziku članaka i svjetsku medijsku pokrivenost.

\section{Montenegro} Gport

\section{Correspondence:}

\section{B. Banjevic}

Army of Montenegro, Airforce military of Montenegro, Military airport "Knjaz Danilo" Podgorica, Montenegro

E-mail: boris.banjevic@gmail.com 


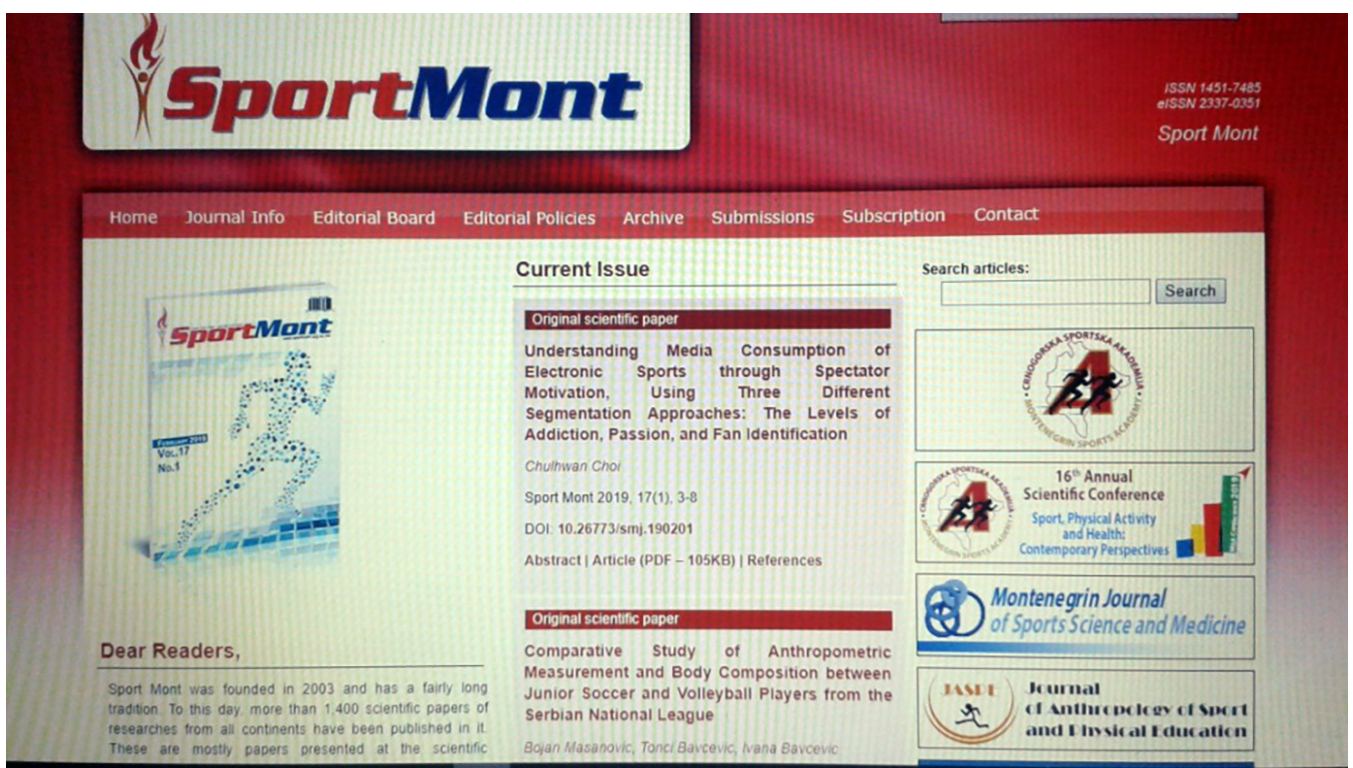

Slika 1. Internet strana časopisa

Sport Mont je, doživljavajući brojne transformacije, prelazio evolutivni put napretka, čije ga tekovine danas postavljaju u ravan najpriznatijih časopisa istog stvaralačkog područja u cijelom svijetu. Egzistiranje časopisa u današnjem obliku je rezultat stručnog, posvećenog i pregalačkog rada glavnih urednika časopisa i članova uredničkog odbora, koji su uspjeli na ovaj način značaj- no doprinijeti razvoju kineziološke nauke na našim prostorima. Glavni i odgovorni urednici časopisa su prof. dr Duško Bjelica sa Univerziteta Crne Gore i prof. dr Zoran Milošević sa Univerziteta u Novom Sadu. Izvršni urednik je mr Jovan Gardašević sa Univerziteta Crne Gore. Uređivački odbor čini 15 profesora sa Univerziteta Crne Gore, regiona, Evrope i Sjeverne Amerike.

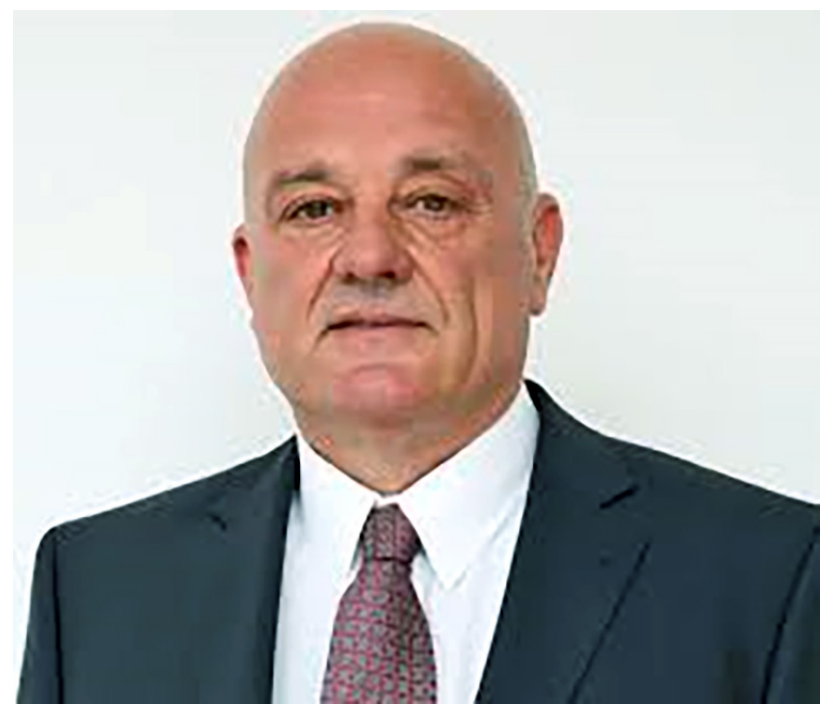

Slika 2. Prof. dr Duško Bjelica

Do sada su izvršene brojne analize sadržaja iz časopisa Sport Mont, a cilj ovog rada je selektovanje članaka objavljenih od strane predavača sa Fakulteta za sport i fizičko vaspitanje-Nikšić, u periodu između 2016. i 2018. godine, po odgovarajućim naučnim oblastima kojima pripadaju. Na ovaj način će biti omogućen lakši pristup i pretraga onim autorima koji se budu služili radovima objavljenim u pomenutom vremenskom okviru.

\section{Metod rada}

U ovom radu biće korišćena metoda analize sadržaja, koja se efikasno primjenjuje u raznovrsnim područjima ljudskog rada i stvaralaštva. Ona podrazumijeva korišćenje pisanih izvora kao osnovne jedinice izvora informacija. Ovdje su to svi naučni član- ci pod autorstvom ili koautorstvom predavača Fakulteta za sport i fizičko vaspitanje-Nikšić, objavljeni u časopisu Sport Mont između 2016. i 2018. godine. Ukupno je objavljeno 35 naučnih radova. Klasifikovani su prema sljedećim naučnim oblastima: sportski trening i metodika treninga; ishrana i suplementacija; fizičko vaspitanje djece sa posebnim potrebama; antropologija sporta; sociologija sporta i naučno izdavaštvo; korektivna gimnastika; istorija sporta; menadžment i marketing u sportu.

\section{Rezultati}

Nakon sprovedene kompletne analize sadržaja iz Sport Mont-a, izvršena je klasifikacija radova u osam oblasti, kako je prikazano u tabeli 1. 
Tabela 1. Podjela radova prema naučnim oblastima

\begin{tabular}{lc}
\hline Naučna oblast & Broj radova \\
\hline Sportski trening i metodika treninga & 7 \\
Ishrana i suplementacija & 2 \\
Fizičko vasp. djece sa posebnim potrebama & 1 \\
Antropologija sporta & 16 \\
Sociologija sporta i naučno izdavaštvo & 3 \\
Korektivna gimnastika & 1 \\
Istorija sporta & 2 \\
Menadžment i marketing u sportu & 3 \\
\hline
\end{tabular}

Sportski trening i metodika treninga kao sastavni dio trenažne tehnologije, omogućavaju transformacione procese pojedinih segmenata antropološkog statusa sportiste i usavršavanje tehničko-taktičkih elemenata, što u krajnjem vodi ka postizanju vrhunskih sportskih dostignuća. Iz ovog veoma važnog segmenta su prikazani sljedeći radovi: "Repulsion of the futsal ball depending on the pressure in it" (Bjelica, Milošević, Talović i Bajramović, 2018), "Six-week preparation period and its effects on transformation movement speed" (Gardašević, Bjelica i Vasiljević, 2016), "The effects of the training in the preparation period on the repetitive strength transformation with cadet level football players" (Gardašević, Bjelica, Vasiljević i Milašinović, 2016), "The strength of kicking the ball after preparation period with U15 football players" (Gardašević, Bjelica i Vasiljević, 2017), "The impact of the preparation period on endurance at football players U16" (Gardašević, Bjelica i Ćorluka, 2018), "Methods for evaluation of some psychomotor abilities" (Krivokapić i Tanase, 2016), Theories of tiredness in sport" (Krivokapić, 2017).

Ishrana i suplementacija je naučna oblast koja se ubrzano razvija. Sve više istraživača se usmjerava na nju, a sve veći broj naučnih članaka ukazuje na vezu između adekvatne ishrane i sportskih postignuća. Radovi iz ove oblasti su: "Knowledge of physicial education students on sports nutrition" (Bjelica, Kezunović i Gardašević, 2016), "Waist circumference as an indicator abdominal obesity in middle age" (Vasiljević, Gardašević, Kezunović i Bojanić, 2017).

Fizičko vaspitanje djece sa posebnim potrebama je zasebna oblast u okviru kineziologije, koja u posljednje vrijeme, shodno rezultatima brojnih studija iz ovog domena, doprinosi rasvjetljavanju brojnih okolnosti prilikom primjene raznovrsnih formi i oblika fizičkog vježbanja kod djece sa posebnim potrebama. Ova oblast u Sport Mont časopisu je bila zastupljena radom: “The effect of regular physical education in the transformation motor development of children with special needs" (Bojanić, Ljubojević i Bubanja, 2016).

Antropologija je naučna disciplina koja se bavi konstrukcijom antropoloških modela, utvrđivanjem strukture i relacija antropoloških karakteristika, kao i utvrđivanjem relacija u odnosu na odgovarajuće kineziološke fenomene. Zastupljeni radovi iz ove oblasti su sljedeći: "Relationship between foot length measurements and body height: A prospective regional study among adolescents in central region of Kosovo"
(Arifi, Gardašević i Mašanović, 2018), "Effect of morphological characteristics and motor abilities on the execution of technical elements in alpine skiing" (Bubanja, Milašinović i Bojanić, 2016), "Differences in the morphological characteristics and body composition of football players of HSC Zrinjski Mostar and FC Siroki Brijeg in Bosnia and Herzegovina" (Ćorluka, Bjelica, Vasiljević, Bubanja, Georgiev i Zeljko, 2018), "Relationship between sitting height measurements and standing height: A prospective regional study among adolescents in eastern region of Kosovo" (Gardašević, 2018), "Relationship between tibia length measurements and standing height: A prospective regional study among adolescents in southern region of Kosovo" (Gardašević, Mašanović i Arifi, 2018), "Sport-specific morphology profile: differences in anthropometric characteristics among elite soccer and handball players" (Gušić, Popović, Molnar, Mašanović i Radaković, 2017), "Effects of various physical education curriculum on motor skills in students of final grades in primary school" (Ljubojević, Muratović i Bubanja, 2016), "Structure of cognitive abilities and skills of lifeguards" (Ljubojević, Muratović i Bubanja, 2017), "Relationship between foot length measurements and body height: A prospective regional study among adolescents in eastern region of Kosovo" (Mašanović, Gardašević i Arifi, 2018), "Relationship between foot length measurements and standing height: A prospective regional study among adolescents in southern region of Kosovo" (Mašanović, Gardašević i Arifi, 2018), "Standing height and its estimation utilizing arm spam and foot length measurements in Dinaric Alps population: A systematic review" (Mašanović, 2018), "Comparative study of anthropometric measurement and body composition between junior basketball and volleyball players from the Serbian national league" (Mašanović, 2018), "Body height and its estimation utilizing arm spam measurements in male adolescents from southern region in Montenegro" (Milašinović, Popović, Matić, Gardašević i Bjelica, 2016), "Body height and its estimation utilizing arm spam measurements in female adolescents from southern region in Montenegro" (Milašinović, Popović, Jakšić, Vasiljević i Bjelica, 2016), "Ranging the results achieved in biomotoric and specific-motoric skills in handball players and non-athletes cadet" (Muratović i Bojanić, 2016), "Standing height and its estimation utilizing foot measurements in adolescents from western region in Kosovo" (Popović, Gardašević, Mašanović, Arifi i Bjelica, 2017). 


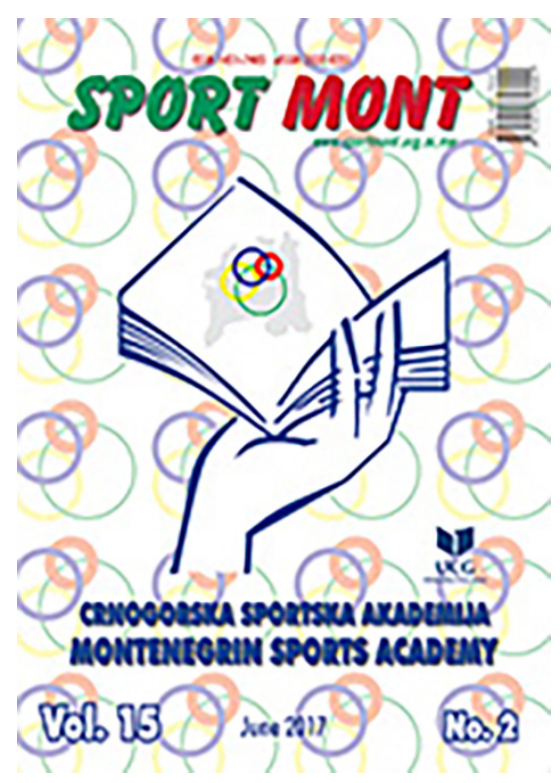

Slika 3. Naslovna strana časopisa (2017)

Iz oblasti sociologije sporta i naučnog izdavaštva, koje objašnjavaju odnose pojedinca prema grupi ili široj društvenoj zajednici, zakonitosti unutar složenih pedagoških okvira, kao i trendove kretanja i razvoja stručnog i naučnog izdavaštva u sportskim naukama, zastupljeni su sljedeći radovi: "Youth and sport in Montenegro" (Maroš, 2018), "A content analysis of published articles in Montenegrin journal of sportsojscience and medicine from 2012 to 2018" (Maroš, 2018), "Research and writing development in the area of sport science publishing in Montenegro" (Popović, 2018).

Korektivna gimnastika predstavlja strukturalni segment kineziterapije i primjenjuje se u prevenciji i korekciji funkcionalnih poremećaja i promjena na lokomotornom aparatu. Iz ove oblasti je objavljen naučni rad: "Frequencu of foot deformity among students of Faculty for sport and physical education" (Muratović, Vasiljević, Bojanić i Ljubojević, 2016).

$\mathrm{U}$ oblasti istorija sporta, koja se bavi izučavanjem istorijskih fakata i okolnosti bitnih za razumijevanje evolutivnih tokova kompleksnog razvoja sporta, dati su sljedeći radovi: "Historical development of skiing with special retrospection in Montenegro" (Milašinović i Popović, 2016), "Historical development of skiing: Case study in Durmitor area" (Milašinović i Bjelica, 2017).

Menadžment i marketing u sportu, u uslovima specifičnih socio-ekonomskih prilika današnjice, predstavljaju veoma bitne karike u složenom sistemu društvenih odnosa u sportu. Iz ovih oblasti su izdvojeni radovi: "Ethical dilemmas of sport advertising” (Bjelica, Gardašević, Vasiljević i Popović, 2016), "Attitudes of consumers from Autonomous province of Vojvodina toward advertising through sport in relation with the frequencu of watching sports events" (Mašanović, 2018), "Model of advertising communication in sport” (Popović i Milašinović, 2016).

\section{Diskusija}

U ovom radu izvršena je klasifikacija naučnih članaka predavača sa Fakulteta za sport i fizičko vaspitanje u Nikšiću, koji su obljavljeni u časopisu Sport Mont između 2016. i 2018. godine. Metodom analize sadržaja utvrđeno je da su isti iz sljedećih oblasti: sportski trening i metodika treninga (7), ishrana i suplementacija (2), fizičko vaspitanje djece sa posebnim potreba- ma (1), antropologija sporta (16), sociologija sporta i naučno izdavaštvo (3), korektivna gimnastika (1), istorija sporta (2) i menadžment i marketing u sportu (3).

Najveći broj istraživanja je iz antropologije sporta, što i ne čudi obzirom na veliki opseg ove naučne discipline i sami značaj problematike koju tretira. U ovim radovima pažnja je bila usmjerena na utvrđivanju raznovrsnih uticaja i relacija između pojedinih segmenata antropološkog statusa, kao i njihov prediktivni aspekt na raznovrsne kineziološke manifestacije. Ipak, tematika se u najvećem broju studija odnosila na ispitivanje relacija pojedinih antropometrijskih pokazatelja kod adolescenata sa teritorija Crne Gore i Kosova. Dobijeni rezultati ovih istraživanja, daju značajan doprinos u objašnjavanju etnografskih razlika i utvrđivanju sličnosti i odstupanja od prethodno utvrđenih standarda u ispitivanim odnosima fokusiranih morfoloških mjera. Ostala prikazana istraživanja iz ove kompleksne oblasti rasvjetljavaju brojne nedoumice vezane za kompleksno funkcionisanje "sistema čovjek" u najraznovrsnijim kretnim postavkama. Poslije antropologije sporta, najviše radova je bilo iz oblasti sportskog treninga i metodike treninga. U njima je težište stavljeno na utvrđivanju efekata dejstva raznovrsnih trenažnih tretmana na unaprijeđivanje kondicionih potencijala $\mathrm{u}$ pojedinim sportovima. Takođe, u kontekstu efikasnosti primjene djelotvornih trenažnih transformacionih procesa, u pojedinim radovima su se razmatrale i metode za procjenu pojedinih psihomotoričkih sposobnosti, kao i teorije zamora u sportu. U krajnjem, rezultanta svih studija iz ove oblasti je razotkrivanje načina efikasnog djelovanja na one antropološke operatere koji dovode do vrhunskog sportskog postignuća. Ovdje je takođe naglašen broj radova iz menadžmenta i marketinga u sportu. Ove teme su doprinijele shvatanju brojnih dešavanja u sportu i tržišnoj ekonomiji u kontekstu savremenog poimanja socioekonomskih fenomena. Zapravo, govorilo se o kreiranju konceptualnog modela reklamne komunikacije, etičkim dilemama sportskog oglašavanja i markentiškim djelatnostima u sportu postavljenim u međuodnos sa potrebama i stavovima potrošača, odnosno kupaca sportskih proizvoda. Radovi autora iz oblasti sociologije sporta i naučnog izdavaštva, takođe su dali značajne činjenične postavke bitne za poimanje složenih socioloških fenomena u uslovima ubrzanog razvoja sporta i njegovih pratećih 
djelatnih kategorija, kao i tokova savremenog stručnog i naučnog izdavaštva u sportskim naukama. Po svojoj zastupljenosti slijede radovi koji se tiču ishrane i suplementacije, a koji su, umnogome doveli do razumijevanju međuzavisnosti adekvatnog nutritivnog statusa i pojedinih pokazatelja koji se direktno ili indirektno povezuju sa zdravljem čovjeka. Iako su autori iz istorije sporta, fizičkog vaspitanja djece sa posebnim potrebama i korektivne gimnastike zastupljeni sa po jednim radom, oni su obzirom na značaj predmeta proučavanja ipak ostavili značajan trag u izdanjima časopisa u navedenom vremenskom periodu. Ustanovljena su brojna stanovišta na kojima počivaju postulati pravilnog shvatanja evolutivnog razvoja sporta, adekvatne primjene sredstava i metoda fizičkog vježbanja u specifičnim uslovima kod djece sa posebnim potrebama i značaju statike i dinamike stopala kao segmenta lokomotornog aparata čovjeka. Sumirajući sve naprijed rečeno, konstatuje se izuzetna stručna, naučna i stvaralačka djelatnost predavača sa Fakulteta za sport i fizičko vaspitanje u Nikšiću, koja je u krajnjem dovela do značajnih zakonomjernih naučnih odrednica, koje će, sada i ubuduće, biti vodilja u pravcima daljeg istraživačkog aktiviteta i unaprijeđivanja složenih procesa $u$ fizičkom vaspitanju i sportu.

\section{Acknowledgements}

There are no acknowledgements.

\section{Conflict of Interest}

The authors declare that there are no conflicts of interest.

Received: 13 July 2019 | Accepted: 20 August 2019 | Published: 11 October 2019

\section{References}

Arifi, F., Gardašević, J., \& Mašanović, B. (2018). Relationship between foot length measurements and body height: A prospective regional study among adolescents in central region of Kosovo. Sport Mont, 16(3), 69-74.

Bjelica, D., Gardašević, J., Vasiljević, I., \& Popović, S. (2016). Ethical dilemmas of sport advertising. Sport Mont, 14(3), 41-43.

Bjelica, D., Milošević, Z., Talović, M., \& Bajramović, I. (2018). Repulsion of the futsal ball depending on the pressure in it. Sport Mont, 16(2), 61-67.

Bojanić, D., Ljubojević, M., \& Bubanja, M. (2016). The effect of regular physical education in the transformation motor development of children with special needs. Sport Mont, 14(1), 21-23.

Bubanja, M., Milašinović, R., \& Bojanić, D. (2016). Effect of morphological characteristics and motor abilities on the execution of technical elements in alpine skiing. Sport Mont, 14(3), 11-14.

Ćorluka, M., Bjelica, D., Vasiljević, I., Bubanja, M., Georgiev, G., \& Zeljko, I. (2018). Differences in the morphological characteristics and body composition of football players of HSC Zrinjski Mostar and FC Siroki Brijeg in Bosnia and Herzegovina. Sport Mont, 16(2), 77-81.

Gardašević, J., Bjelica, D., \& Vasiljević, I. (2016). Six-week preparation period and its effects on transformation movement speed. Sport Mont, 14(1), 13-16.

Gardašević, J., Bjelica, D., Vasiljević, I., \& Milašinović, R. (2016). The effects of the training in the preparation period on the repetitive strength transformation with cadet level football players. Sport Mont, 14(2), 31-33.

Gardašević, J., Bjelica, D., \& Vasiljević, I. (2017). The strength of kicking the ball after preparation period with U15 football players. Sport Mont, 15(2), 39-42.

Gardašević, J., Bjelica, D., \& Corluka, M. (2018). The impact of the preparation period on endurance at football players U16. Sport Mont, 16(1), 21-24.
Gardašević, J. (2018). Relationship between sitting height measurements and standing height: A prospective regional study among adolescents in eastern region of Kosovo. Sport Mont, 16(2), 15-19.

Gardašević, J., Mašanović, B., \& Arifi, F. (2018). Relationship between tibia length measurements and standing height: A prospective regional study among adolescents in southern region of Kosovo. Sport Mont, 16(3), 51-55.

Gušić, M., Popović, S., Molnar, S., Mašanobić, B., \& Radaković, M. (2017) Sport-specific morphology profile: differences in anthropometric characteristics among elite soccer and handball players. Sport Mont, 15(1), 3-6.

Krivokapić, D., \& Tanase, G. (2016). Methods for evaluation of some psychomotor abilities. Sport Mont, 14(2), 17-19.

Krivokapić, D. (2017). Theories of tiredness in sport. Sport Mont, 15(1), 35-37.

Ljubojević, M., Muratović, A., \& Bubanja, M. (2016). Effects of various physical education curriculum on motor skills in students of final grades in primary school. Sport Mont, 14(1), 25-28.

Ljubojević, M., Muratović, A., \& Bubanja, M. (2017). Structure of cognitive abilities and skills of lifeguards. Sport Mont, 15(1), 27-29.

Maroš, M. (2018). Youth and sport in Montenegro. Sport Mont, 16(2), 97-100.

Maroš, M. (2018). A content analysis of published articles in Montenegrin journal of sports science and medicine from 2012 to 2018. Sport Mont, 16(3), 97-102.

Mašanović, B., Gardašević, J., \& Arifi, F. (2018). Relationship between foot length measurements and body height: $A$ prospective regional study among adolescents in eastern region of Kosovo. Sport Mont, 16(1), 9-13.

Mašanović, B., Gardašević, J., \& Arifi, F. (2018). Relationship between foot length measurements and standing height: A prospective regional study among adolescents in southern region of Kosovo. Sport Mont, 16(2), 27-31.

Mašanović, B. (2018). Standing height and its estimation utilizing arm spam and foot length measurements in Dinaric Alps population: A systematic review. Sport Mont, 16(2), 101-106.

Mašanović, B. (2018). Comparative study of anthropometric measurement and body composition between junior basketball and volleyball players from the Serbian national league. Sport Mont, 16(3), 19-24.

Mašanović, B. (2018). Attitudes of consumers from Autonomous province of Vojvodina toward advertising through sport in relation with the frequencu of watching sports events. Sport Mont, 16(3), 91-96.

Milašinović, R., \& Popović, S. (2016). Historical development of skiing with special retrospection in Montenegro. Sport Mont, 14(1), 39-41.

Milašinović, R., Popović, S., Matić, R., Gardašević, J., \& Bjelica, D. (2016). Body height and its estimation utilizing arm spam measurements in male adolescents from southern region in Montenegro. Sport Mont, 14(2), 21-23.

Milašinović, R., Popović, S., Jakšić, D., Vasiljević, I., \& Bjelica, D. (2016). Body height and its estimation utilizing arm spam measurements in female adolescents from southern region in Montenegro. Sport Mont, 14(23), 15-18.

Milašinović, R., \& Bjelica, D. (2017). Historical development of skiing: Case study in Durmitor area. Sport Mont, 15(1), 39-41.

Muratović, A., \& Bojanić, D. (2016). Ranging the results achieved in biomotoric and specific-motoric skills in handball players and non-athletes cadet. Sport Mont, 14(1), 29-31.

Muratović, A., Vasiljević, I., Bojanić, D., \& Ljubojević, M. (2016). Frequencu of foot deformity among students of Faculty for sport and physical education. Sport Mont, 14(3), 19-20.

Popović, S., \& Milašinović, R. (2016). Model of advertising communication in sport. Sport Mont, 14(1), 31-38.

Popović, S., Gardašević, J., Mašanović, B., Arifi, F., \& Bjelica, D. (2017). Standing height and its estimation utilizing foot measurements in adolescents from western region in Kosovo. Sport Mont, 15(3), 3-7.

Popović, S. (2018). Research and writing development in the area of sport science publishing in Montenegro. Sport Mont, 16(3), 31-36.

Vasiljević, I., Bjelica, D., Kezunović, M., \& Gardašević, J. (2016). Knowledge of physicial education students on sports nutrition. Sport Mont, 14(1), 17-19.

Vasiljević, I., Gardašević, J., Kezunović, M., \& Bojanić, D. (2017). Waist circumference as an indicator abdominal obesity in middle age. Sport Mont, 15(1), 21-22. 